Хірургічна стоматологія

УДК 616.314-089.843

DOI 10.11603/2311-9624.2018.2.8811

(СН. С. Гутор, Н. О. Твердохліб, О. В. Авдєєв

ДВН3 «Тернопільський державний медичний університет імені І. Я. Горбачевського»

\title{
Клінічні спостереження автотрансплантації зубів як альтернативи імплантації
}

Резюме. Вивчення ділянки дефекту зубного ряду, післяекстракційної лунки, стану трансплантованого зуба за допомогою рентгенологічного обстеження є актуальним на сьогодні.

Мета дослідження - підвищення ефективності комплексного лікування пацієнтів із дефектами зубного ряду шляхом їх відновлення автотрансплантацією зубів.

Матеріали і методи. Обстежено 10 пацієнтів без соматичних захворювань: 7 жінок та 3 чоловіків віком від 23 до 30 років, які проживають у м. Тернополі. Використовуючи клінічні та рентгенологічні методи дослідження, у них було виявлено по одному періодонтитному зубу, що не підлягав терапевтичному лікуванню, наявність інтактних третіх молярів. Автотрансплантацію та клінічні спостереження проведено 2 пацієнтам.

Результати досліджень та їх обговорення. За даними клінічного та рентгенологічного обстеження, автотрансплантація у пацієнтів, як хірургічний метод лікування, є достатньо ефективною. Результати клінічних спостережень показали, що одним із шляхів відновлення цілості зубного ряду може бути автотрансплантація. Для її проведення мають бути визначені показання до хірургічного лікування із застосуванням сучасних методів діагностики, а також згода пацієнтів.

Висновки. Для проведення автотрансплантації необхідно починати з показання до їі проведення: наявність інтактних третіх молярів; наявність перших молярів, що не підлягають консервативному лікуванню; вік пацієнта; стан здоров'я; добра гігієна порожнини рота; попереднє ретельне рентгенологічне обстеження. Автотрансплантація третього моляра, як хірургічний метод лікування, $є$ достатньо ефективною, доступною, малозатратною операцією для пацієнтів за відсутності першого моляра.

Ключові слова: треті та перші моляри; автотрансплантація; рентгенологічне обстеження; хірургічний метод лікування.

\author{
(СН. С. Гутор, Н. О. Твердохлиб, А. В. Авдээв
}

ГВУЗ «Тернопольский государственный медицинский университет имени И. Я. Горбачевского»

\section{Клинические наблюдения автотрансплантации зубов как альтернативы имплантации}

Резюме. Изучение участка дефекта зубного ряда, послеэкстракционной лунки, состояния трансплантированного зуба с помощью рентгенологического обследования является актуальным на сегодня. Цель исследования - повышение эффективности комплексного лечения пациентов с дефектами зубного ряда путем их восстановления автотрансплантацией зубов.

Материалы и методы. Обследовано 10 пациентов без соматических заболеваний: 7 женщин и 3 мужчин в возрасте от 23 до 30 лет, которые живут в г. Тернополе. Используя клинические и рентгенологические методы исследования, в них было обнаружено по одному периодонтитному зубу, который не подлежал терапевтическому лечению, наличие интактных третьих моляров. Автотрансплантацию и клинические наблюдения проведены 2 пациентам.

Результаты исследований и их обсуждение. По данным клинического и рентгенологического обследования, автотрансплантация у пациентов, как хирургический метод лечения, является достаточно эффективной. Результаты клинических наблюдений показали, что одним из путей восстановления целостности зубного ряда может быть автотрансплантация. Для ее проведения должны быть определены показания к хирургическому лечению с применением современных методов диагностики, а также согласие пациентов.

Выводы. Для проведения автотрансплантации следует начинать с показания к ее проведению: наличие интактных третьих моляров; наличие первых моляров, не подлежащих консервативному лечению; возраст пациента; состояние здоровья; хорошая гигиена полости рта; предварительное 
тщательное рентгенологическое обследование. Автотрансплантация третьего моляра, как хирургический метод лечения, является достаточно эффективной, доступной, молозатратною операцией для пациентов при отсутствии первого моляра.

Ключевые слова: третьи и первые моляры; автотрансплантация; рентгенологическое обследование; хирургический метод лечения.

\section{@N. S. Hutor, N. O. Tverdokhlib, O. V. Avdeev}

I. Horbachevsky Ternopil State Medical University

\section{Clinical observation of teeth autotransplantation as an alternative of implantation}

Summary. Study of the tooth range defect area, the post-extraction alveolar socket, the state of the transplanted tooth by using an X-ray examination is relevant nowadays.

The aim of the study - to increase the efficiency of complex treatment of patients with defects in the tooth range by using dental autotransplantation for their restoration.

Materilas and Methods. 10 patients without somatic diseases were examined: 7 women and 3 men, aged 23 to 30, residents of Ternopil town. Using clinical and radiological methods of examination, they had found by ones periodontitis tooth that was not subject to therapeutic treatment, the presence of intact third molars. Autotransplantation and clinical observations were performed on 2 patients.

Results and Discussion. According to clinical and radiological examination data, autotransplantation in patients, as a surgical method of treatment, is sufficiently effective. Clinical observations have proven that one way to restore the integrity of the tooth range can be autotransplantation. For its conduct, indications for surgical treatment with the use of modern diagnostic methods should be determined, patients' consent is required.

Conclusions. To conduct autotransplantation one should begin with indications for its implementation: the presence of intact third molars; presence of the first molars not subject to conservative treatment; age of the patient; health status; good hygiene of the oral cavity; preliminary careful X-ray examination. Autotransplantation of the third molar as a surgical method of treatment is a sufficiently effective, accessible, cost-effective operation for patients in the absence of the first molar.

Key words: third and first molars; autotransplantation; X-ray examination; surgical method of treatment.

Вступ. Для досягнення успішного хірургічного та ортопедичного результату лікування втрати зубів велике значення має застосування методики трансплантації зубів, що буває девітальною та вітальною. При девітальній трансплантації спочатку видаляють зуб, пломбують його кореневі канали, верхівки коренів підлягають резекції, після чого зуб трансплантують у підготовлену альвеолу. При вітальній трансплантації канали не пломбують, пульпа зуба залишається «живою» $[1,12]$. Для успішного проведення трансплантації, в зубі добре повинна бути збережена коронка; корені зубів не повинні мати сильних викривлень або сильно розходитися; у ньому не повинно бути ураження глибоким карієсом [2, 5, 11]. Трансплантацію власних зубів було запропоновано давно, але не застосовують її дуже часто для заміни втрачених зубів або зубів, що не прорізалися $[7,9,10]$. Зазвичай для трансплантації використовують власні зуби мудрості для за- міщення дефекту зубного ряду на верхній або нижній щелепі, а також пересадку зміщених різців та премолярів $[4,16]$. У пацієнтів віком 15-30 років трансплантація власних зубів є багатообіцяльною, досить економічною при заміщенні дефектів зубного ряду [2, 18]. Частка успішних трансплантацій за десятилітній період становить більше $80 \%$ [6, 19].

Перевагами та недоліками трансплантації власних зубів, порівняно з імплантацією, $є$ [3, 8, 20]:

- власні зубні трансплантати:

- переваги (добрі шанси на приживлення, економність, може бути використано у підлітків, наявність остеоіндуктивного потенціалу);

- недоліки (схильність до карієсу, не можна застосовувати на всіх ділянках зубного ряду);

- штучні імплантати:

- переваги (добрі шанси на приживлення, відсутність карієсу, застосовують в усіх ділянках зубного ряду); 
- недоліки (дороговартісні, вік пацієнта більше 18 років, немає остеоіндуктивного потенціалу).

Стоматологи-хірурги мають враховувати характер дефекту зубного ряду, наявність показань до трансплантації, чим швидше провести трансплантацію, тим менше ускладнень необхідно очікувати у майбутньому [14, 17]. Для розрахунків наявності місця в зубному ряді та стану трансплантованого зуба варто використовувати параклінічні методи, зокрема рентгенографію: прицільну, внутрішньоротову, ортопантомограму, комп'ютерну томографію та 3D-відтворення $[4,13]$. Обстеження стану післяекстракційної лунки, ділянки дефекту зубного ряду, трансплантованого зуба за допомогою рентгенологічного методу є актуальним на сьогодні. Окрім того, висока вартість імплантації, тривалість післяопераційного періоду (до 0,5 року) не завжди влаштовують пацієнтів [7, 15].

Метою дослідження було підвищення ефективності комплексного лікування пацієнтів із дефектами зубного ряду шляхом їх відновлення автотрансплантацією зубів.

Матеріали і методи. На базі кафедри хірургічної стоматології ДВНЗ «Тернопільський державний медичний університет імені I. Я. Горбачевського МО3 України» проведе-

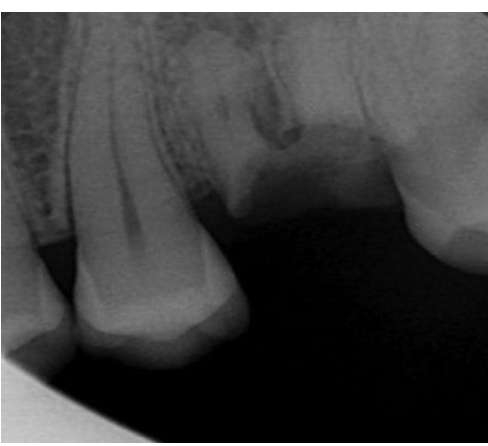

Puc. 1. Прицільна ренгенограма 16 зуба пацієнтки В., 23 роки.

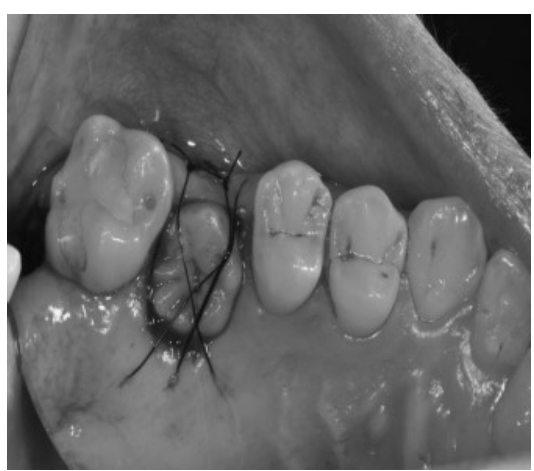

Puc. 4. Після трансплантації 18 зуба.

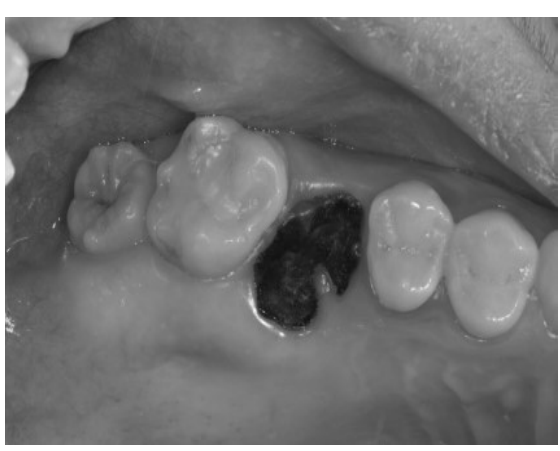

Puc. 2. Клінічний стан 18 та 16 зубів.

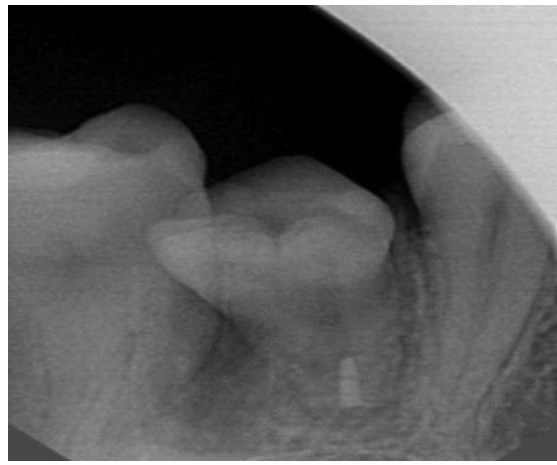

Puc. 5. Рентгенограма одразу після трансплантації в лунку 16 зуба. но стоматологічне обстеження 10 пацієнтів (суб'єктивне та об'єктивне): 7 жінок та 3 чоловіків віком від 23 до 30 років жителів м. Тернополя, у яких було виявлено по одному періодонтитному зубу, який не підлягав терапевтичному лікуванню, наявність інтактних третіх молярів, без соматичних захворювань. Обстеження усіх пацієнтів проводили з використанням клінічного та рентгенологічного методів дослідження. Лікування 2 пацієнтів складалося із автотрансплантації третього моляра у лунку видалення першого.

Результати досліджень та ї обговорення. Проведене обстеження (клінічне, рентгенологічне) показало, що усім пацієнтам було показано проведення хірургічного методу лікування хронічного періодонтиту - видалення першого моляра. Згоду на операцію автотрансплантації третього моляра отримано у 2 пацієнтів та попереджено про можливі ускладнення. Іншим пацієнтам було проведено видалення першого моляра 3 наступним традиційним ортопедичним лікуванням. Перед операцією виконували професійну гігієну порожнини рота, уточнювали особливості будови альвеолярного відростка, визначали найраціональніший хід операції.

Приклад 1. Рис. 1-10. 


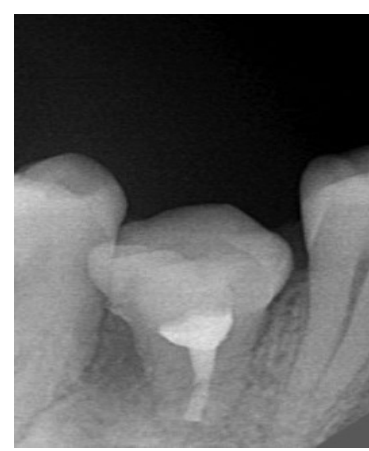

Puc. 7. Рентгенограма трансплантованого 18 зуба через місяць після ендодонтичного лікування.

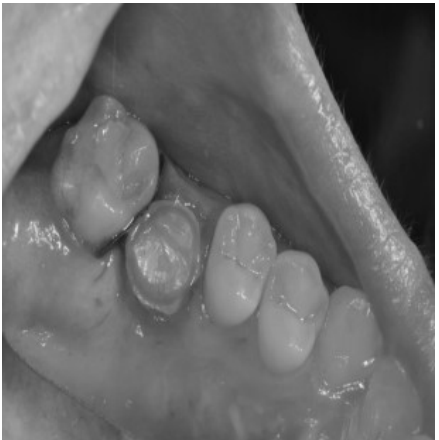

Puc. 8. Етап підготовки до протезування штучною коронкою.

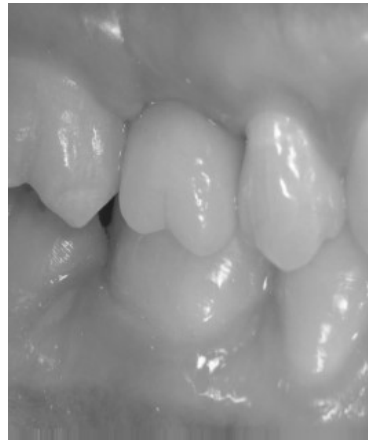

Puc. 9. Коронка 16 зуба на моделі.

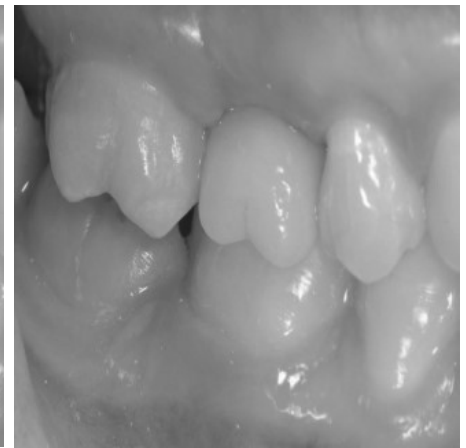

Puc. 10. Цільнокерамічна реставрація трансплантованого 18 зуба.

Пацієнтка В., 23 роки. Скарги на наявність зруйнованого зуба на верхній щелепі справа. Об'єктивно: 18 зуб інтактний, коронкова частина 16 зуба повністю зруйнована. За даними рентгенологічного обстеження, 16 зуб не підлягає терапевтичному лікуванню. Клінічний діагноз: хронічний гранулюючий періодонтит 16 зуба. Лікування: під туберальною та палатинальною анестезією Sol.Ubistesin forte $1,7 \mathrm{ml}$ проведено видалення 16 та 18 зубів. Після екстракції верхівку кореня третього моляра ретроградно пломбували біокерамічним силером (EndoSequence Root Repair Material).

Міжкореневі перегородки лунки 16 зуба видаляли для усунення неспівпадання між альвеолою та коренями 18 зуба. Трансплантували 18 в лунку 16 зуба, фіксували Seralon 5/0 шляхом накладання зближувальних швів. Призначали протизапальну, антибактеріальну та знеболювальну терапії протягом 7 днів (приклад 1):

- Аугментин - 875/125 мг по 1 табл. 2 рази на добу, 7 днів.

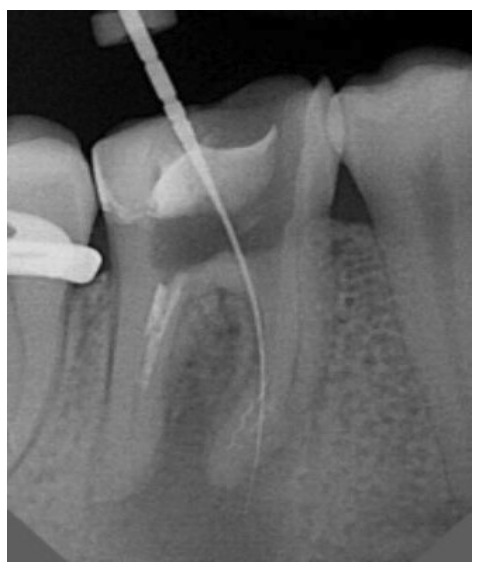

Puc. 11. Прицільна ренгенограма 46 зуба пацієнтки М., 27 років.

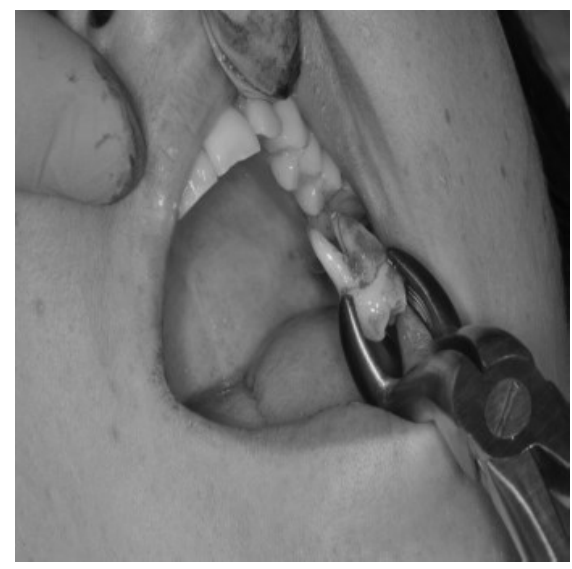

Puc. 12. Видалення 28 зуба.
• Пробіз - по 1 капс. 2 рази на добу, 7 днів;

- Диклоберл® 50 - по 1 табл. 2 рази на добу (100 мг/добу) 5 днів;

- Нурофен Форте 400 мг - по 1 табл. 2-3 рази на добу (1200 мг/добу), 3 дні;

- Смекта - за потребою;

Шви знято на 7 день. Через один місяць проводили обтурацію кореневих каналів із застосуванням гутаперчі та AH Plus за традиційною методикою $з$ подальшою підготовкою до встановлення штучної коронки (рис. 10).

Приклад 2. Рис. 11-15.

Пацієнтка М., 27 років. Скарги на періодичний біль при накушуванні в ділянці зуба нижньої щелепи справа. Об’єктивно: 28 інтактний, у 46 зубі наявна пломба, перкусія слабоболюча. Терапевтичне лікування не можливе у зв'язку з обтурацією кореневих каналів резорцин-формаліновою пастою. За даними рентгенологічного обстеження, у 46 зубі наявна перфорація у медіальному корені, недопломбований дистальний корінь, розрідження 


\section{Хірургічна стоматологія}

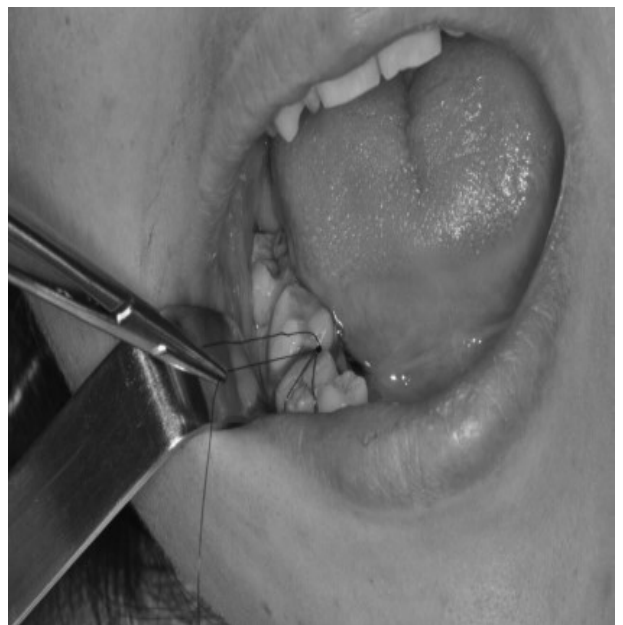

Puc. 14. Після трансплантації 28 зуба в лунку 46 зуба.

кісткової тканини навколо верхівок коренів (рис. 11). Клінічний діагноз: хронічний гранулюючий періодонтит 46 зуба. Лікування: під туберальною, палатинальною, торусальною анестезіями Sol.Ubistesin forte 3,4 ml проведено видалення 28 та 46 зубів. Міжкореневі перегородки лунки 46 зуба були видалені для усунення неспівпадання між альвеолою та коренями 28 зуба. Трансплантували 28 зуб у лунку 46 зуба, фіксували Seralon 5/0 шляхом накладання зближувальних швів. Призначали протизапальну, антибактеріальну та знеболювальну терапії протягом 7 днів (див. перший приклад).

Шви знято на 7 день. Рекомендовано з'явитися повторно для рентген-контролю приживлення 28 зуба та подальшого лікування із відновлення оклюзії ортопедичною конструкцією.

Таким чином, за результатами клінічних спостережень, одним із шляхів відновлення цілості зубного ряду може бути автотран-

\section{Список літератури}

1. Outcome of tooth transplantation: Survival and success rates 17-41 years posttreatment / E. M. Czochrowska, A. Stenvik, B. Bjercke, B. U. Zachrisson // Am. J. Orthod. Dentofacial Orthop. - 2002. - Vol. 121. - P. 110-119.

2. Current state of dental autotransplantation / D. Herrera-Gimbernat, C. Recio-Lora, D. Torres-Lagares [et al.] // Med. Oral Patol. Oral Cir. Bucal. - 2011. Vol. 16. - P. 948-952.

3. Tooth transplantations: A descriptive retrospective study / R. Kallu, F. Vinckier, C. Politis [et al.] // Int. J. Oral Maxillofac. Surg. - 2005. - Vol. 34. - P. 745-755.

4. Anatomically shaped tooth and periodontal regeneration by cell homing / K. Kim, C. H. Lee, B. K. Kim, J. J. Mao // J. Dent. Res. - 2010. - Vol. 89. - P. 842-847. 5. Autogenous tooth transplantation: Evaluation of pulp

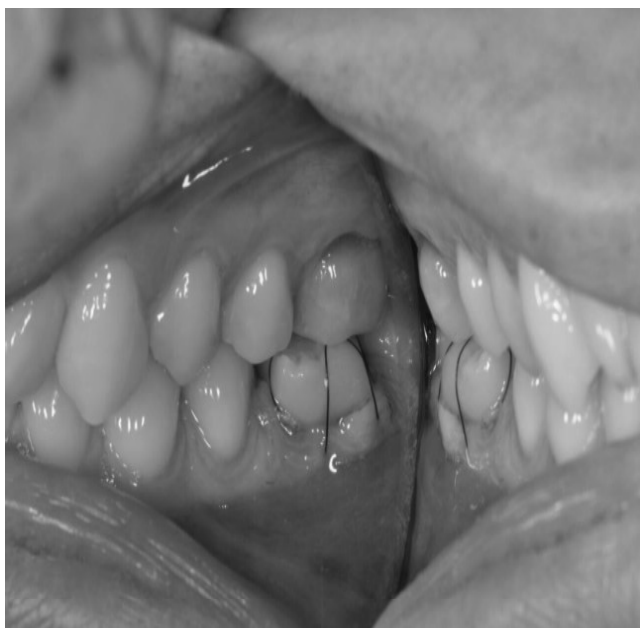

Puc. 15. Стан оклюзії після трансплантації.

сплантація. Для ії проведення мають бути визначені показання до хірургічного лікування із застосуванням сучасних методів діагностики, повинна бути згода пацієнтів.

Висновки. 1. Для проведення автотрансплантації мають бути чітко визначені показання до їі проведення: наявність інтактних третіх молярів; наявність перших молярів, що не підлягають консервативному лікуванню; вік пацієнта; стан здоров'я; добра гігієна порожнини рота; попереднє ретельне рентгенологічне обстеження.

2. Автотрансплантація третього моляра, як хірургічний метод лікування, $є$ достатньо ефективною, доступною, молозатратною операцією для пацієнтів за відсутності першого моляра.

Перспективою подальших досліджень буде проведення додаткових досліджень щодо визначення типу зрощення кореня трансплантованого зуба за допомогою цементу і за даними рентгенограми.

tissue regeneration / M. Marques-Ferreira, M. F. RabaçaBotelho, L. Carvalho [et al.] // Med. Oral Patol. Oral Cir. Bucal. - 2011. - Vol. 16. - P. 984-989.

6. Mejàre $\mathrm{B}$. A prospective study on transplantation of third molars with complete root formation / B. Mejàre, K. Wannfors, L. Jansson // Oral Surg. Oral Med. Oral Pathol. Oral Radiol. Endod. - 2004. - Vol. 97. - P. 231-238. 7. Nethander G. Autogenous free tooth transplantation with a two-stage operation technique / G. Nethander // Swed Dent. J. - 2003. - Vol. 161, Suppl. P. 1-51.

8. Tooth auto-transplantation as an alternative treatment option: A literature review / T. Nimčenko, G. Omerca, V. Varinauskas [et al.] // Dent. Res. J. (Isfahan). - 2013. Vol.10. - P. 1-6. 
9. Dental autotransplant: Case report / N. M. Pacini, D. T. Nery, D. R. De Carvalho [et al.] // RSBO. - 2012. Vol. 9. - P. 108-113.

10. Park J. H. Tooth autotransplantation as a treatment option: A review / J. H. Park, K. Tai, D. Hayashi // J. Clin. Pediatr. Dent. - 2010. - Vol. 35. - P. 129-135.

11. Sartaj R. Biological tooth replacement / R. Sartaj, P. Sharpe // J. Anat. - 2006. - Vol. 209. - P. 503-509.

12. Schmidt S. K. Tooth autotransplantation: An overview and case study / S. K. Schmidt, D. G. Cleverly // Northwest Dent. - 2012. - Vol. 91. - P. 29-33.

13. Autotransplantation of impacted teeth: A report of 3 cases and review of the literature // Quintessence Int. 2009. - Vol. 40. - P. 589-595.

14. Tooth transplantation and cryopreservation: State of the art / L. Temmerman, G. A. De Pauw, H. Beele, L. R. Dermaut // Am. J. Orthod. Dentofacial Orthop. 2006. - Vol. 129. - P. 691-695.

15. Tsukiboshi M. Autotransplantation of teeth / M. Tsukiboshi. - Quintessence Publishing Co, Inc, 2001. -

\section{References}

1.Czochrowska,E.M.,Stenvik, A., Bjercke,B., \&Zachrisson, B.U. (2002). Outcome of tooth transplantation: survival and success rates 17-41 years posttreatment. Am. J. Orthod. Dentofacial Orthop., 121, 110-119.

2. Herrera-Gimbernat, D., Recio-Lora, C., Torres-Lagares, D., Romero-Ruiz, M.M., \& Gutiérrez-Pérez, J.L. (2011). Current state of dental autotransplantation. Med. Oral Patol. Oral Cir. Bucal., 16, 948-952.

3. Kallu, R., Vinckier, F., Politis, C., Mwalili, S., \& Willems, G. (2005). Tooth transplantations: A descriptive retrospective study. Int. J. Oral Maxillofac. Surg., 34, 745755.

4. Kim, K., Lee, C.H., Kim, B.K., \& Mao, J.J. (2010). Anatomically shaped tooth and periodontal regeneration by cell homing. J. Dent. Res., 89, 842-847.

5. Marques-Ferreira, M., Rabaça-Botelho, M.F., Carvalho, L., Oliveiros, B., \& Palmeirão-Carrilho, E.V. (2011). Autogenous tooth transplantation: Evaluation of pulp tissue regeneration. Med. Oral Patol. Oral Cir. Bucal., 16, 984-989.

6. Mejàre, B., Wannfors, K., \& Jansson, L. (2004). A prospective study on transplantation of third molars with complete root formation. Oral Surg. Oral Med. Oral Pathol. Oral Radiol. Endod., 97, 231-238.

7. Nethander, G. (2003). Autogenous free tooth transplantation with a two-stage operation technique. Swed Dent. J. Suppl., 161,1-51.

8. Nimčenko, T., Omerca, G., Varinauskas, V., Bramanti, E., Signorino, F., \& Cicciù, M. (2013). Tooth auto-transplantation as an alternative treatment option: A literature review. Dent. Res. J. (Isfahan), 10, 1-6.

9. Pacini, N.M., Nery, D.T., De Carvalho, D.R., Lima, N.J.Jr., Miranda, A.F., \& Macedo, S.B. (2012). Dental autotransplant: Case report. RSBO, 9, 108-113.

10. Park, J.H., Tai, K., \& Hayashi, D. (2010). Tooth autotransplantation as a treatment option: a review.
$192 \mathrm{p}$.

16. Alveolar bone changes in autogenous tooth transplantation / A. Waikakul, J. Punwutikorn, J. Kasetsuwan, S. Korsuwannawong // Oral Surg. Oral Med. Oral Pathol. Oral Radiol. Endod. - 2011. - Vol. 111. - P. 1-7.

17. Indications for the use of auto-transplantation of teeth in the child and adolescent / K. Waldon, S. K. Barber, R. J. Spencer, M. S. Duggal // Eur Arch Paediatr Dent. - 2012. - Vol. 13. - P. 210-216.

18. Yau C. K. Tooth autotransplantation as a treatment option / C. K. Yau // Hong Kong Med. Diary. - 2009. Vol. 14. - P. 21-24.

19. Comparison of prognosis of separated and nonseparated tooth autotransplantation / K. Yoshino, N. Kariya, D. Namura [et al.] // J. Oral Rehabil. - 2013. Vol. 40. - P. 33-42.

20. A retrospective survey of autotransplantation of teeth in dental clinics / K. Yoshino, N. Kariya, D. Namura [et al.] // J. Oral Rehabil. - 2012. - Vol. 39. - P. 37-43.

\section{J. Clin. Pediatr. Dent., 35, 129-135.}

11. Sartaj, R., \& Sharpe, P. (2006). Biological tooth replacement. J. Anat., 209, 503-509.

12. Schmidt, S.K., \& Cleverly, D.G. (2012). Tooth autotransplantation: An overview and case study. Northwest Dent., 91, 29-33.

13. Tatli, U., Kürkçü, M., Cam, O.Y., \& Büyükyilmaz, T. (2009). Autotransplantation of impacted teeth: A report of 3 cases and review of the literature. Quintessence Int., 40, 589-595.

14. Temmerman, L., De Pauw, G.A., Beele, H., \& Dermaut, L.R. (2006). Tooth transplantation and cryopreservation: State of the art. Am. J. Orthod. Dentofacial Orthop., 129, 691-695.

15. Tsukiboshi, M. (2001). Autotransplantation of teeth. Quintessence Publishing Co., Inc.

16. Waikakul, A., Punwutikorn, J., Kasetsuwan, J., \& Korsuwannawong, S. (2011). Alveolar bone changes in autogenous tooth transplantation. Oral Surg. Oral Med. Oral Pathol. Oral Radiol. Endod., 111, 1-7.

17. Waldon, K., Barber, S.K., Spencer, R.J., \& Duggal, M.S. Indications for the use of auto-transplantation of teeth in the child and adolescent. Eur. Arch. Paediatr. Dent., 13, 210-216.

18. Yau, C.K. (2009). Tooth autotransplantation as a treatment option. Hong Kong Med. Diary, 14, 21-24.

19. Yoshino, K., Kariya, N., Namura, D., Noji, I., Mitsuhashi, K., \& Kimura, H. (2013). Comparison of prognosis of separated and non-separated tooth autotransplantation. J. Oral Rehabil., 40, 33-42.

20. Yoshino, K., Kariya, N., Namura, D., Noji, I., Mitsuhashi, K., \& Kimura, H. (2012). A retrospective survey of autotransplantation of teeth in dental clinics. J. Oral Rehabil., 39, 37-43.

Отримано 06.04.18 